\title{
Fermilab
}

Managed by Fermi Research Alliance, LLC for the U.S. Department of Energy Office of Science

\section{Maximizing the efficiency of plasma-based lepton accelerators}

\section{Cooperative Research and Development Agreement Final Report}

\section{CRADA Number: FRA-2018-0047}

\section{Fermilab Technical Contact: Alexey Burov}

Summary Report

January 23, 2020 


\section{NOTICE}

This report was prepared as an account of work sponsored by an agency of the United States government. Neither the United States government nor any agency thereof, nor any of their employees, makes any warranty, express or implied, or assumes any legal liability or responsibility for the accuracy, completeness, or usefulness of any information, apparatus, product, or process disclosed, or represents that its use would not infringe privately owned rights. Reference herein to any specific commercial product, process, or service by trade name, trademark, manufacturer, or otherwise does not necessarily constitute or imply its endorsement, recommendation, or favoring by the United States government or any agency thereof. The views and opinions of authors expressed herein do not necessarily state or reflect those of the United States government or any agency thereof.

Available electronically at http://www.osti.gov/bridge

Available for a processing fee to U.S. Department of Energy and its contractors, in paper, from:

U.S. Department of Energy Office of Scientific and Technical Information

P.O. Box 62

Oak Ridge, TN 37831-0062

phone: 865.576 .8401

fax: 865.576 .5728

email: mailto:reports@adonis.osti.gov

Available for sale to the public, in paper, from:

U.S. Department of Commerce

National Technical Information Service

5285 Port Royal Road

Springfield, VA 22161

phone: 800.553 .6847

fax: 703.605.6900

email: orders@ntis.fedworld.gov

online ordering: http://www.ntis.gov/ordering.htm 
In accordance with Requirements set forth in Article $\mathrm{X}$ of the CRADA, this document is the final CRADA report, including a list of Subject Inventions, to be forwarded to the Office of Science and Technical Information as part of the commitment to the public to demonstrate results of federally funded research.

CRADA number: $\quad$ FRA-2018-0047

CRADA Title: $\quad$ Maximizing the efficiency of plasma-based lepton accelerators

Parties to the Agreement: Radiasoft, LLC and Fermi Research Alliance, LLC

\section{Abstract of CRADA work:}

The next generation of particle accelerators will likely rely on compact accelerating structures to achieve very high gradients; one such candidate is accelerators using plasmas for the accelerating structures. Because of the small length scales of these structures, they can also be prone to the beam break-up instability, which would spoil the quality of the beam and leave it unsuitable for many applications. The goal of this project is to develop a framework for understanding the instabilities in plasma accelerators using language from conventional linear accelerator instabilities, such as wake fields and wake functions. During the course of this Phase I, we benchmarked a pseudo-spectral particle-in-cell code to determine its suitability for computing wake functions, and developed a procedure for extracting wake functions from a sequence of simulations using this code.

\section{Summary of Research Results:}

First, we have developed a procedure for extracting the wake functions from field data generated by the FBPIC code. To the best of our knowledge this is the first time wake functions have been extracted from particle-in-cell simulations of plasma accelerators.

Second, we used the hollow plasma channel to develop and study the approaches we would later use for plasma accelerators. After determining that computing an impedance would be untenable, we benchmarked FBPIC to analytic results for the hollow plasma channel and developed an approach for selectively exciting wake field modes in plasma structures.

Third, having established FBPIC's accuracy in the hollow channel, we applied the techniques we developed to study wake functions in an axisymmetric blowout plasma wakefield accelerator. We developed a diagnostic to test if the trailing wake fields could be derived from a wake potential, and computed monopole and dipole wake functions to parameterize the linear response of the plasma wave to a small perturbing charge. 
Fourth, we determined where nonlinear loading of the plasma wave would begin. Then, using the techniques we developed for isolating the wake functions in the unloaded plasma wave and the resulting wake functions, we began studying how adding a $300 \mathrm{pC}$ gaussian witness bunch affects the wake functions computed for the unloaded case.

\section{Related Reports, Publications, and Presentations:}

S. D. Webb, N. M. Cook, D. L. Bruhwiler, A. Burov, V. Lebedev, and S. Nagaitsev, “Theoretical and computational modeling of a plasma wakefield BBU instability", 13th International Computational Accelerator Physics Conference (ICAP'18), Key West, Florida, USA

\section{Subject Inventions listing:}

None

Report Date: January 23, 2020

Technical Contact at Fermilab: Alexey Burov

This document contains NO confidential, protectable or proprietary information. 